\title{
Website Quality and Online Shopping of E-Tail Stores in Nigeria
}

\author{
N. Gladson Nwokah, Sarah Walter Ntah \\ Department of Marketing, Faculty of Management Sciences, Rivers State University, Port Harcourt, Nigeria \\ Email: nwokah.gladson@ust.edu.ng
}

How to cite this paper: Nwokah, N.G. and Ntah, S.W. (2017) Website Quality and Online Shopping of E-Tail Stores in Nigeria. Journal of Service Science and Management, 10, 497-517. https://doi.org/10.4236/jssm.2017.106039

Received: October 31, 2017

Accepted: December 12, 2017

Published: December 15, 2017

Copyright ( 2017 by authors and Scientific Research Publishing Inc. This work is licensed under the Creative Commons Attribution International License (CC BY 4.0).

http://creativecommons.org/licenses/by/4.0/ (c) (i) Open Access

\begin{abstract}
This study examined the relationship between website quality and online shopping of E-tail stores in Nigeria. A survey research design was adopted. The source of data used in this study was mainly primary data from the issuance of questionnaire and secondary data from the review of relevant literature on both variables which formed the basis for the argument. Out of a total of three hundred and eighty four (384) copies of the questionnaire distributed, three hundred and sixty nine (369) copies were fit for analysis and analyzed using Spearman's Rank Order Correlation Coefficient with the aid of Statistical Package for Social Sciences (SPSS). The findings of the study reveal amongst others that website aesthetics strongly relates with perceived trust and perceived-ease-of-use of online shoppers in Nigeria. The study concludes that website quality dimensions significantly relates with online shopping of e-tail stores in Nigeria. The study filled the lacuna in the literature of internet marketing as a contribution to knowledge and recommendations amongst others that the e-tail firms should pay keen attention to web security if they must gain more customer patronage as it has the highest positive relationship with online shopping with various suggestions for other researchers interested in the same or similar topic of study.
\end{abstract}

\section{Keywords}

Website, Quality, Online-Shopping, E-Tail, Nigeria

\section{Background to the Study}

The spread of internet technologies has created a change of consumers' shopping behavior from the traditional means to a modern and entirely different attitude and platform as consumers are no longer restricted and constrained by time, and distance [1]. Obviously, the internet is a relatively new platform for 
communication and exchange of relevant data for the daily activities of both firms and their customers which can be explained by the rapid increase and growth in the use of broadband technologies as records from the University of California, Los Angeles (UCLA) center for communication policy in 2001, which reveals that online shopping has become the third most popular internet events with the inception of email, instant messaging, web browsing and other social network activities [2]. Similarly, the 2012 reports from Interactive Media in Retail Group (IMRG) shows that internet business has been on the rise and that business-2-consumers (B2C) sales will be above 1 trillion euro ( $\$ 1.25$ trillion) mark by 2013 and the total number of online shoppers will increase to approximately 3.5 billion [3].

In support, [3] noted that a report from IMRG sales index which tracks trends in internet business revealed that e-tailing sites have received over $66 \%$ visit via mobile devices. Further, [1] noted that the advent of internet facilities has transformed the commercial activities between the e-tailing stores especially in Nigeria as online shopping site like Konga, Jumia and Jiji, etc. are using their websites to provide product information's and various customer services. Further, [4] noted that online shopping is among the widely accepted channel for buying at buyers' convenience as it covers purchase of clothes, pets, electronics and many more. The study also observed that time, trust, convenience, product variety and privacy are major factors that attributes to online shopping behavior. Moreover, online shopping market has shown a good potential from 2004 to 2008 as the percentage of individuals who have ordered products online or through the internet rose significantly from $22 \%$ to $34 \%$ and among the purchases, the young people are fond to be much interested in online services [5]. Online shopping has experienced a recent growth during the recent years due to its advantage for both consumers and retailers such as shopping at round the clock facilities, decreased dependence to traditional store visits, decreased travelling costs, increased market area, reduced overhead expenses and wide product offerings even as studies shows that $80 \%$ of the world online population has ordered goods via internet platform in recent years [6]. In accordance, [7] affirmed that consumers now make frequent purchases online than in the traditional store. His report also revealed that more than 5000 consumers make at least 2 times purchases online in every three months with evidence which shows that shoppers now make over $51 \%$ of their buying via internet devices.

Moreover, e-tailing activities have attracted lots of authors in the field of marketing and management as its importance in the business world cannot be overemphasized. [8] [9] [10] observed that in recent times, there has been an increased growth in e-tailing firms' spending which will continue even in the future. He noted that retail spending on web accounted for over $7.4 \%$ (i.e. $\$ 1.67$ trillion) and could increase from $8.8 \%$ to $12.4 \%$ by $2018-2019$. Supportively, [8], asserted that internet as a global medium has gained a sharp interest and attractiveness among marketing practitioners. [9] noted that online shopping envi- 
ronments are playing significant roles in ensuring an ultimate interactivity between marketers and their consumers. However, despite the voluminous contributions of website attributes towards the successfulness of e-tailing activities, it would appear that researchers in the field of marketing have done very little in showing empirical results of the influence of website quality on e-tailing consumers shopping attitude especially in the Nigerian context.

Therefore, this present study seeks to empirically investigate the influence of website quality and online shopping attitude of e-tail stores in Nigeria and this serves as the point of departure of this study.

\section{Problem of Online Shopping}

There are series of problems that are constantly faced by online shoppers such as trust and security. Recent statistics shows that approximately $30 \%$ of online users do not get committed towards online shopping as a result of low trust and these have made online marketing a tasking activity [8]. Further, [11] observed that lots of under graduates in Nigeria used the internet for fraudulent sake and they are commonly called yahoo-yahoo life style. He added that they fake their identities online, and also on social media sites which have also contributed in making internet business a risky one. [12] equally observed that fraud has been existing in Nigeria especially in cities like Lagos even before internet was introduced to Nigerians. His report shows that these internet fraudsters send scams or deceitful messages and emails despite many arrests of those cut in the illegal acts. More also, [13] mentioned that consumers search at e-tail stores does not necessarily lead to actual purchase. There could be other factors influencing consumer decisions such as: site complexity, delay acquisition period, poor interactivity, insufficient product offerings etc. which can hamper the willingness and the ability of customer to purchase online. The study of [13], shows that there is a need for e-tail store managers in developing countries especially in $\mathrm{Ni}$ geria to pay keen attention to the characteristics of their websites.

Hence, the study seeks to empirically examine the impact of website quality on online shopping of e-tail-stores in Nigeria.

\section{Theoretical Foundations}

Every topic in any field of study has its root and foundation and as such website quality and online shopping is not an exemption. Hence, this study review theories and models that served as foundation to the basic concepts of website quality and online shopping.

\subsection{Quality Evaluation Model (QEM)}

A quality model (QM) is a set of attributes and of relationships between criteria which provides a framework for specifying quality requirements and evaluation. In a bid to measure or evaluate the quality of a website, [14] noted that the first model identifying quality within electronic device was in the mid 1970s. He 
added that the International Organization for Standardization (ISO) alongside the International Electro-technical Commission (IEC) finished the development of the new standard "ISO 9126-Information Technology criteria and guidelines which are segmented into six basic characteristics-functionality, usability, efficiency, reliability, maintainability and portability.

\subsection{Technology Acceptance Model (TAM)}

The objective of the TAM is to provide an explanation of the determinants of computer acceptance and to provide better explanation about user behavior across a broad range of end-user computing technologies and user populations with a theoretic back up on attitude toward Subjective norm, behavioral intention actual behavior, external variables, perceived usefulness and perceived-ease-of-use [15]. The TAM holds that two specific beliefs known as Perceived-ease-of-use and Perceived-usefulness are responsible for the determination of one's behavioral intention to adopt or consume an innovative item, product or service [16] [17] noted that perceived ease of use can be the degree to which a person believes that using a technology will be free of effort. It is thus a construct tied to an individual's assessment of the effort involved in the process of using an introduced item. Further, [18] stated that perceived usefulness is referred to as the degree to which a person believes that using a particular technology will increase his or her duty, action or performance. In accordance, [17] argued that technology acceptance model (TAM) holds a critical argument that the variable "Perceived usefulness" possess the ability to affect the variable "Perceived-ease-of-use" because, (other things being equal), the easier a technology is to use, the more useful it can be to the user. For instance, a consumer who wants to buy an item online may only find the website say "Jumia.com" or "Konga.com" useful if the sites are easy to use and accessible. In other words, the usefulness of an item, a brand or a service is determined by the extent to which such item is easy to use or accessible by the user.

\section{Concept of Website Quality}

The rapid growth of web applications increases the need to evaluate web applications which resulted to valuable works like Web-QEM (Web Quality Evaluation Method) tried to objectively evaluate the web applications; however, evaluation of websites are completely subjective, depending mostly on professionals' judgments [19]. The term quality is a complex word which denotes the extent to which an item conforms to a set of standards. In accordance to this view, [19] stated that quality is the extent to which an item (i.e. product, good or service) meets customers' needs or expectations. Similarly, [20] observed that the quality of an electronic service environment refers to the effectiveness and efficiency of consumers' purchase online. This implies that web quality entails the compatibility of websites in terms of enabling online shoppers make purchases at their own convenience and comfort. 


\section{Dimensions of Website Quality}

\subsection{Web Aesthetics}

Aesthetics includes the artistic and creative elements of an internet environment with core purpose of achieving beautiful and pleasing appearance or effect [21]. Besides the general importance of aesthetics in website building, researchers are supposed to specifically be interested in how such aesthetic impressions are formed by online shoppers since it is evident that the process of human aesthetic perception is very complex given that an aesthetic evaluation is shaped by several physical features of the perceived stimuli (e.g. shape, color, complexity) as well as by the individual characteristics of the site visitor like previous experiences [21]. Further, [21] noted that design and style of websites are elements that play significant role in shaping the online experience and the buying decision making process. He also made a comparison between the internet and face-face (traditional) shopping by stating that just like shoppers in traditional shops where more time may be spent, the online shop has its aesthetics as the first contact. Consequentially, one could deduce that since online buying does not have sales person who stands in front or a receptionist that welcomes a visitor and acquaint him or her with detailed information, site aesthetics seems to play the same roles as the visitor navigates. Website appearance contains the "welcome", "go in" and "go out" information which serves as a director that a visitor needs to comfortably transact online. More also, [22] noted that aesthetics are part of the elements that can affect a user's first impressions of about the credibility and accessibility of websites. Visual impressions are an integral part of the online shoppers' experience and so developers in IT discipline benefit from knowledge about managing visual impressions that are programed in the aesthetic visual designs [23].

\subsection{Web Interactivity}

Web interactivity entails the extent to which an e-tail store's website allows online shoppers enjoy mutual relationship with their fellows without unnecessary break in transmission. In support, [21] stated that the interactivity of internet allows online sellers to enhance the web experience by providing the customers with more personalized services and empowering interaction with other online shoppers wishing to share their feelings and suggestions. He further noted that electronic interactivity comprises of the two basic elements namely-personalization and networking. Same study shaded light on how internet provide customized interactive environment for both buyers and sellers via the use of technology-based devices. Internet has provided interactivity in variant perspectives such as online consumer auctions, online bartering, virtual classifieds, modernized pattern of peer-to-peer (P2P) interactions even when it does not involve exchange of money [15] Online users still engaged in music file transfers, videos, chatting and many more which are part of the virtual interaction that has gained rapid popularity among the online marketing activities [24]. Network effects were viewed in the 1990s as the main internet facility in communication that is 
suspected to bring about online users' empowerment and distribution of market knowledge through interaction between online clients, yet literature in regards to users' forums, bulletin boards, chat-rooms, guest books essential web experience elements is rather limited [21]. Additional research is vital in order to assess the exact role and effects of such elements as well as the trends online business activities. The improvements in the internet over time have made new systems available to business organizations thereby providing online environments as social media via online communities being a good example [25]. Similarly, [26] observed that customer's cognitive, affective commitment and active relationship with a brand through the means of website or other computer-based entities are designed to communicate brand values which are characterized by the dimensions of dynamic and sustained instruments.

\subsection{Web Security}

Website security is the effort made by online firms to protect their customers' information from the hands of unauthorized users. Customers online reveal a lot of their personal data such as date of birth, full name, occupation, bank account numbers, security codes, marital status and many more which goes to say that the need for security is paramount .This is true even as [26], argued that security and privacy are directly related to trust and are important components of effective commercial websites. Further, [1] stated that internet security can be viewed based on organizational perspective as the ability to protect information resources from unauthorized access, modification and destruction while on consumers' perspective. It is the perceived guarantee that no unauthorized parties will have access to communication between them (consumers) and the online business organization while the transaction takes place and after information has be captured by the organization. Moreover, technology provides websites that has proven a fertile ground for marketing and advertising which pose significant implications for privacy. It also serves as a platform for electronic business firms to create favorable relations with consumers that offers all of the tools needed by an organization attempting to fully incorporate relationship marketing with unique customer data-gathering capabilities [27].

\section{Concept of Online Shopping}

Consumers buying behavior has always been a popular marketing topic, extensively reviewed and debated many years ago even as no modern marketing textbook is complete without a discus on the issues that concerns consumers' behavior. Online shopping involves processes that may lead to consumers' purchase via the use of internet facilities such as searching online for product information, product comparison, ordering of a product and payment in a website. Since the inception of internet, internet marketers have not stopped the quest to understanding consumers' online shopping attitude. Correspondently, [15] posited that a thorough comprehension of the means of virtual shopping and the atti- 
tude of electronic consumers (i.e. E-Consumers) is a vital occasion for firms that transact business deals online. They also observed that the concept of online shopping has attracted writers' attention which is evident in the fact that in the year 2001 alone, more than 120 relevant academic papers were published with focus on the same subject matter.

In addition, [21] stated that online shopping is made up of faceless and intangible activities with the high potential risk. They also noted that online shopping intentions can be explained with the integration of TAM and trust. Their study shaded more lights on the characteristics of online shopping and what make it different from the traditional buying environment. In the same light, when a consumer shops in a traditional store say Every Day Supermarket, he/she is bound to meet the receptionist, sales persons and other front desk representatives in a face-to-face contact. In online shopping, the situation is different as the consumer finds him/herself in an internet environment where he/she is only required to click a button to see product information, make comparison, place order and make payments at a faster paste. Supportably, [20] stated that electronic commerce has made life easy and innovative for individuals and groups making online consumers' shopping different from the physical market, where they can touch and feel tangibility of a product item unlike the web-based shopping environment. He also observed that price, time saving and convenience are part of the essential elements that results to certain online shopping behavior. E-commerce is essential with the fact that it has provided several positive events including the sustained outbreak of broadband that has enhanced online shopping comfort and the decline of certain brick-and-mortar retailers' activities [14].

\section{Measures of Online Shopping}

\subsection{Perceived Trust}

Perceived trust is the feeling of confidence and security from one party to another [28]. Trust occurs when an individual or group of persons (first party) believes that the other person (second party) will not harm or take advantage of them in any situation [15]. In the internet world, users lack physical interactions with the e-tailing firms sales personnel's and payments are usually made via credit cards which increases the probability that online shoppers' financial information exposed may fall into the hands of unauthorized users [29]. Similarly, [17] observed that in most cases online shoppers suffer the risk of receiving products that are different from the originally ordered products thereby increasing their negative perception towards the service providers. [13] emphasized on the importance of online trust and argued that it minimizes specific problem of risk that may be encountered by online shoppers. However, several scholars in the field of online marketing posit that it is easier to convince online customers to remain with an e-tail store once those customers perceive the firm to be trustworthy. In the same vein, [30] identified the fact that perceived trust of online 
shoppers plays crucial roles in determining the successfulness of websites. Further, [31] over the years perceived trust has being one of the greatest concerns of online business firms and has been perceived to influence online shoppers' behavior. Same study also observed that building trust online is usually more hectic compared to the traditional shopping method. This follows to say that e-tailing marketing personnel's may have more work load in building perceived trust of online shoppers' since there are tendencies that online shopping environment could be more risky than the physical and traditional stores. Further, [32] noted that online trust is multi-dimensional. They also stated that the design of the interface for online transaction serves as part of the factors that affect online shoppers' trust. [16] observed that online shoppers' usually bear trust in their mind before actually engaging in any online transaction. This implies that perceived trust is inherent in individual's body system which surfaces during purchase.

\subsection{Perceived-Ease-of-Use}

Perceived-ease-of-use refers to consumer's perception is about how easy it will be while navigating on the website [6]. The term perceived-ease-of-use (PEOU) gained its popularity via the technology acceptance model (TAM) proposed by Davis in 1989. He further defined Perceived-ease-of-use as the degree to which an individual believes using a particular item would be free from struggle. More also, [1] noted that perceived-ease-of-use is the extent to which an innovation is simple to comprehend. [1] also opined that perceived-ease-of-use describes consumer's ability to effectively and efficiently make use of an item and properly evaluate its advantages. Additionally, [33] noted that the willingness to shop online may be low if the online store or website lacks ease in searching and comparing products categories. He suggested that, online marketing practitioners should endeavor to make their sites searchable and easily accessible to consumers. Same study also observed that making web designs and portals less sophisticated and adopting web atmospherics that is friendly could be a key to attract visitors.

\section{Technology Adoption as a Moderating Factor}

Adoption as a mental process is when an individual moves from first being aware about an innovation to final utilization of it which could be in two categories: rate of adoption and intensity of adoption. The former is the relative speed with which farmers adopt an innovation, as one of its pillars, the element of "time". On the other hand, intensity of adoption refers to the level of use of a given technology in any time period [21]. Technology is the means and methods to produce goods and services, including methods of organization as well as physical technique; it is the knowledge/information that permits some tasks to be accomplished more easily, some service to be rendered or the manufacture of a product [34]. The purpose of technology to enhance a given situation and turn 
it into a more desirable level that could aid applicant to do work at ease thereby conserving more time and labor [21]. [34] defines technology adoption as the integration of a new technology into existing practice that mostly begins with a period of trying and some degree of adaptation. Understanding peoples' acceptance and use of information technology is one of the major focuses for discussion in information systems research [35].

\section{Website Quality and Online Shopping}

Website quality entails the effectiveness of website attributes that online consumers come in contact with [36] found that online visitors in China were used for conducting a research that indicated that quality of the website had a significant effect relationship with purchase intention holding satisfaction as a mediating factor. In conclusion, the study that it is critical for online business firm to invest in website quality to gain attraction and retention of online shoppers. [24] developed a model to investigate the relationship between e-service quality, customer satisfactions and intention to make online transactions. Their findings hold that website design, responsiveness, reliability and trust had an impact on the service quality while personalization did not have a significant effect on the service quality and satisfaction of customers. Other studies shows that website quality does not only have a positive impact on consumer beliefs of perceived usefulness and perceived-ease-of-use [37], while [38] proposed that web quality also influence consumer perception of e-tail stores' image and prestige. That is, online shoppers evaluate e-tail stores' reputation and brand value based on the quality of website appearances and other characteristics.

\subsection{Web Aesthetics and Online Shopping}

Web aesthetics has been described with different terminologies such as visual appeal, attractiveness and beauty of user interfaces that has turned major discus on issues that borders on Human-Computer Interaction (HCI) [38]. More also, a good number of researches have established the effect of aesthetics usability of e-tailing business sites [21]. [39] observed in their study that web aesthetics has great link with trust and credibility while [40] holds that visual appearance of websites has effects on online shoppers overall impression about the site. [21] introduced a model of visual complexity (VC) which also explains that the complexity of a web display plays a crucial role in the perception of online shoppers' visual stimuli. Accordingly, [41] submits that special attention must be given to aesthetics, not only because aesthetic elements are often important indicators of e-tailing quality but because they also make up the major clue of vendors and site credibility for the majority of online shoppers. [21] suggested that in order to completely evaluate the degree of aesthetics in a website, each sub-characteristic has to define the weight. For instance, images and color attract more attention than others, they both possess a weight of 0.3 while page's resolution and standard table size has same weight at 0.2. [14] summarized using evaluation and 
relative criteria that aesthetics has over $0.73 \%$ contribution to online shoppers' behavior. This indicates a strong positive correlation between visual displays of websites and online shoppers' attitude. Further, recent empirical studies explored that website characteristic (i.e. web design, website quality, vendor reputation and etc.) is also considered as an important element that controls consumers' trust and their decision to engage in a web-based business transaction [42]. Thus, below are the following hypotheses:

$\mathrm{Ho}_{1}$ : There is no significant relationship between web aesthetics and perceived trust of e-tail stores in Nigeria.

$\mathrm{Ho}_{2}$ : There is no significant relationship between web aesthetics and perceived-ease-of-use of e-tail stores in Nigeria.

\subsection{Web Interactivity and Online Shopping}

Studies like [24] made investigation about the factors that influence online search and purchase intention of online shoppers. They found that elements like the utilitarian and hedonic value of online information and experience were the major determinants of online search intention of consumers. Interactive environments like WhatsApp, Facebook, Instagram, Twitter, etc. has been proven to contribute greatly in e-transacts. The relevance of web interactivity is evidenced in the study of [42] as they found out that $54 \%$ of executives of companies participating in a recently conducted survey agreed that social media interactions was central to their effort to engage consumers in the year 2011. Further, [21] proposed for the adoption of interactive design as means of promoting usability throughout the whole product lifecycle. Another notable study conducted by [43], established a fact that that an increase in the interactivity of a political web site contributes to a corresponding increase in the level of liking. That is, an interactive electronic political forum enhances the level of electorates' followership. Same study suggestion that interactivity found in technological comprises variant concepts and functional features such as e-mail links, feedback forms, chat rooms, and audio or video downloads. In all the various web design attributes, interactivity stands out as a core and distinguished element that has effect on online shoppers' response towards an electronic buying environment [44]. In support, [45] opined that web-based consumers view and consider online interactivity as a criterion in evaluating the success and quality of the sites. Their study agreed that online web interactivity contributes to site sustainability, profit, sales, frequent visit and any other dimensions that could measure site's success. Sales websites that are difficult to navigate and do not provide adequate ways of retrieving product information would reduce the flexibility that online users have in controlling product information displayed; hence in recent times, live chat has been implemented by e-tail stores as a website feature that makes online users to engage in synchronous text chat with sales representatives while shopping via the internet [46]. More also, [47] observed that live chat functions as an additional self-service avenue for consumers to ask for extra information 
or to submit customized requests which have been noted to have resulted to over $305 \%$ return on investment for an internal of 6 months.

Thus, below are the following hypotheses:

$\mathrm{Ho}_{3}$ : There is no significant relationship between web interactivity and perceived trust of e-tail stores in Nigeria.

$\mathrm{Ho}_{4}$ : There is no significant relationship between web interactivity and perceived-ease-of-use of e-tail stores in Nigeria.

\subsection{Web Security and Online Shopping}

Consumers' trust in online shopping has still posed a matter of concern because of its quick and spontaneous developed by individuals without a close legislative control, e-tailing firms' reputation or well-known websites has also an impression impact on consumers' trust and their behavior in selecting the place to shop [48]. A good number of surveys, responded that such concerns affect consumers' willingness to buy items via internet or register on websites [49]. More also, studies have also indicated that most people are willing to put aside privacy concern, i.e. show less attention to security and thereby providing personal information for even small rewards [50]. In contraction, [51] found that most individuals are willing to pay a premium for privacy when privacy information is made prominent and intuitive while many suggest that even privacy-conscious online users are unlikely to pay for online privacy or give up rewards to protect their data. Despite the contradictory view, a report from [52], holds that security consciousness among the online population are high as majority of web users frown at situations that involves the use of their personal information and being monetized to finance free search. Additionally, [53] argued that these electronic indicators of superior security practices can be strong drivers for consumers 'purchase decisions and also their willingness to spend a premium on safe keeping their data. Same study noted that in an experimental study, online shoppers were found to pay over $\$ 0.60$ and more when shopping in an e-tail stores that guarantees security and protection of data.

Thus, below are the following hypotheses:

$\mathrm{Ho}_{5}$ : There is no significant relationship between web security and perceived trust of e-tail stores in Nigeria.

$\mathrm{Ho}_{6}$ : There is no significant relationship between web security and perceived-ease-of-use of e-tail stores in Nigeria.

\subsection{Technology Adoption Relationship with Website Quality and Online Shopping}

The process of adopting new technologies ultimately determines the movement of economic growth and the rate of change in productivity; until reason amount of users adopt a new technology, it may contribute little to our well-being [29]. Understanding people's acceptance and use of electronic device is one of the notable issues in the field of information system research [35]. There have been much of theories and models developed from Social Sciences specifically in Psy- 
chology and Sociology to explain consumers and producers behavior in the adoption of technology which have resulted into a unified theory of acceptance and use of technology (UTAUT). [15] opined that hedonic motivation which stands as a pleasure or fun derived from the use of technology plays a significant role in determining the rate at which technology is accepted and used. For instance, online business firms who perceive the use of social media as fun and pleasant means of communication may want to disseminate information via Twitter, WhatsApp and Facebook. [54] holds that there are several facilitating conditions and elements that moderates technology adoption such as age, gender and experience. Same study observed that consumers who are older in age tend to face challenges in processing new or complex information which affects their ability to learn and use new technology. Similarly, age, gender and experience as identified by [54] could also serve as a moderating variable in online organizational use of technologies. Further, [26] stated that internet self-efficacy is a vital individual difference that serves as a moderating variable. This implies that organizations who place more value on the adoption of new technologies are likely early adopters while those who place less value are likely to be the late majority in adoption of new technologies.

Thus, below are the following hypotheses:

Ho7: Technology Adoption does not significantly moderate the relationship between Website Quality and Online Shopping of E-tail stores in Nigeria.

As can be seen, Figure 1 shows the operational framework of the study. It conceptualizes that the dimensions of Website Quality associates to the measures of Online Shopping with Technology moderating the association. Seven hypotheses are raised from Figure 1 as can be seen. The arrows show a hypothetical linear relationship between the dependent and independent variables. Figure indicates that website quality is operationalized in this study with three dimensions web aesthetics, web interactivity and web security. It also shows that online shopping is measured with two indices, perceived trust and perceived ease of use.

\section{Research Design}

\subsection{Methods}

This Hypotheses study adopted a correlational investigation to investigate the association between web aesthetics and online shopping of e-tail stores in Nigeria. Evidence from the internet statistics (2017) shows that Nigeria as at March, 2017 has 191,835,936 statistics of online users. However, the report from [55] citing the study of Paypal online payment solutions company, over $65 \%$ of Nigeria shop online which follows that $65 \%$ of the Nigerian population is the population of the study which is $124,693,358$. Hence, following this assertion, Krejcie and Morgan sample size determination table was used to determine the sample size of 384. In addition, data for this study was collected via online placement of the questionnaire on the Facebook wall to enable online customers' opinions. 


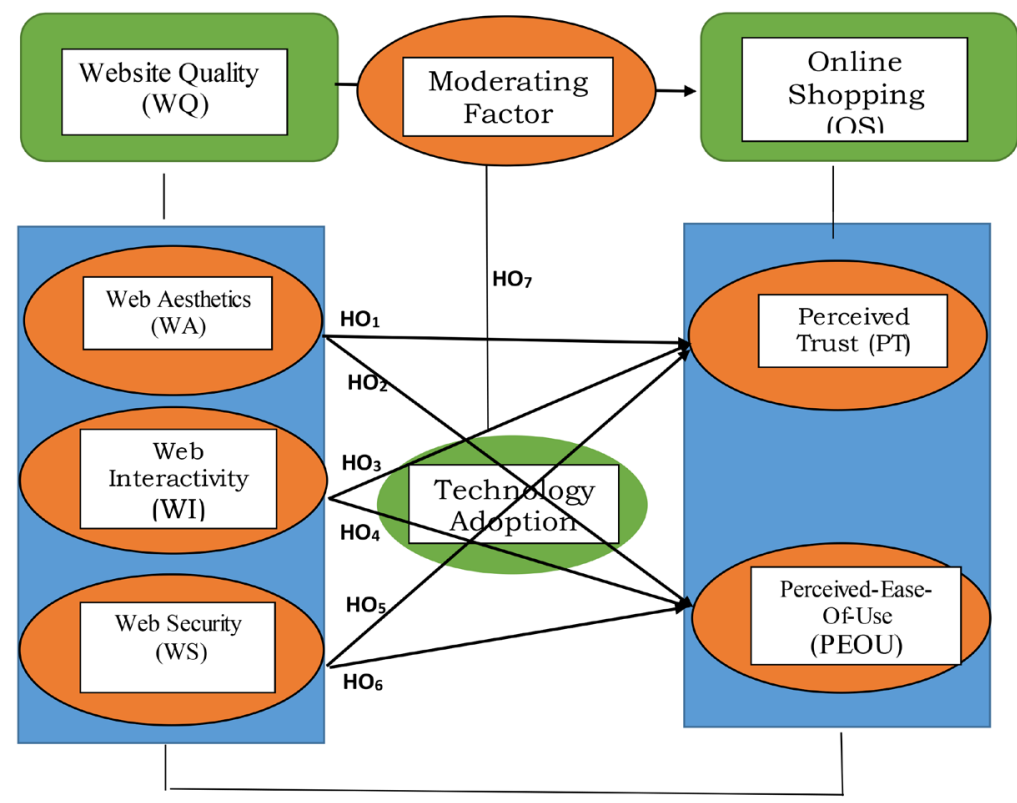

Figure 1. Operational framework of the relationship between website quality and online shopping of e-tail stores in Nigeria. Source: Desk research, 2017.

The questionnaire was structured using A-Five Point Likert scale anchor from strongly disagree to strongly agree to measure the degree of respondent's responsiveness.

\subsection{Reliability and Validity Test}

The instrument used in this study was tested for reliability and Table 1 shows Cronbach alpha above the threshold of 0.7 [56].

The validity of our research instrument is measured by means of construct validity test i.e. proper identification of the variables used whether it could measure what it supposed to measure by experts. Effort was made to ensure the questions were not complex, biased and complicated in order for it to measure what it ought to measure [51].

\subsection{Testing of Research Hypotheses}

The hypotheses were tested using the spearman's rank correlation coefficient and partial correlation. To know the direction of the relationships between the variables, the table below is used to interpret the nature of the relationships.

\subsection{Relationship between Measures of Website Quality and Dimensions of Online Shopping}

\section{Decision:}

As can be seen in Table 2, the spearman rank order correlation coefficient of 0.863 and 0.864 for perceived trust and perceived ease of use respectively show a probability value of $0.000(\mathrm{P}<0.05)$. This result indicates that web aesthetics has a very strong positive and significant relationship between perceived trust 
Table 1. Summary of reliability test.

\begin{tabular}{ccc}
\hline Variable & Scale & Cronbach alpha result \\
\hline Web aesthetics & 5 & 0.81 \\
Web interactivity & 5 & 0.78 \\
Web security & 5 & 0.83 \\
Perceived trust & 5 & 0.88 \\
Perceived ease of use & 5 & 0.77 \\
\hline
\end{tabular}

Source: Survey Data, 2017.

Table 2. Correlation analysis showing the relationship between web aesthetics, perceived trust and perceived-ease-of-use.

\begin{tabular}{|c|c|c|c|c|c|}
\hline \multicolumn{6}{|c|}{ Correlations } \\
\hline & & & $\begin{array}{c}\text { Web } \\
\text { aesthetics }\end{array}$ & $\begin{array}{c}\text { Perceived } \\
\text { trust }\end{array}$ & $\begin{array}{l}\text { Perceived } \\
\text { ease of use }\end{array}$ \\
\hline & & Correlation coefficient & 1.000 & $0.863^{* *}$ & $0.864^{* *}$ \\
\hline & Web aesthetics & Sig. (2-tailed) & 0.000 & 0.000 & 0.000 \\
\hline & & $\mathrm{N}$ & 369 & 369 & 369 \\
\hline & & Correlation coefficient & $* *$ & 1.000 & $* *$ \\
\hline \multirow[t]{5}{*}{$\begin{array}{l}\text { Spearman's } \\
\text { rho }\end{array}$} & Perceived trust & Sig. (2-tailed) & & & \\
\hline & & $\mathrm{N}$ & 369 & 369 & 369 \\
\hline & & Correlation coefficient & $0.864^{\star *}$ & $* *$ & 1.000 \\
\hline & $\begin{array}{l}\text { Perceived } \\
\text { ease of use }\end{array}$ & Sig. (2-tailed) & 0.000 & & \\
\hline & & $\mathrm{N}$ & 369 & 369 & 369 \\
\hline
\end{tabular}

**: Correlation is significant at the 0.05 level (2-tailed). Source: Field Survey Data, 2017, SPSS 21 Output.

and perceived ease of use of E-tail stores. Therefore, this shows that web aesthetics has a significant relationship with perceived trust and perceived ease of e-tail stores in Nigeria.

\section{Decision:}

Table 3 reveals a spearman rank correlation coefficient of 0.988 and 0.980 for perceived trust and perceived-ease-of-use respectively with probability value of $0.000(\mathrm{P}<0.05)$. This result indicates that web interactivity has a very strong positive and significant relationship between perceived trust and perceived-ease-of-use of E-tail stores.

\section{Decision:}

Table 4 reveals a spearman rank correlation coefficient of 0.989 and 0.981 for perceived trust and perceived-ease-of-use respectively with probability value of $0.000(\mathrm{P}<0.05)$. This result indicates that web security has a very strong positive and significant relationship between perceived trust and perceived ease of use of E-tail stores. 
Table 3. Correlation analysis showing the relationship between web interactivity, perceived trust and perceived-ease-of-use.

\begin{tabular}{|c|c|c|c|c|c|}
\hline \multicolumn{6}{|c|}{ Correlations } \\
\hline & & & $\begin{array}{c}\text { Web } \\
\text { interactivity }\end{array}$ & $\begin{array}{l}\text { Perceived } \\
\text { trust }\end{array}$ & $\begin{array}{l}\text { Perceived } \\
\text { ease of use }\end{array}$ \\
\hline \multirow{9}{*}{$\begin{array}{l}\text { Spearman's } \\
\text { rho }\end{array}$} & \multirow{3}{*}{ Web interactivity } & Correlation coefficient & 1.000 & $0.988^{\star *}$ & $0.980^{* *}$ \\
\hline & & Sig. (2-tailed) & & 0.000 & 0.000 \\
\hline & & $\mathrm{N}$ & 369 & 369 & 369 \\
\hline & \multirow{3}{*}{ Perceived trust } & Correlation coefficient & $0.988^{\star *}$ & 1.000 & ** \\
\hline & & Sig. (2-tailed) & 0.000 & & \\
\hline & & $\mathrm{N}$ & 0369 & 369 & 369 \\
\hline & \multirow{3}{*}{$\begin{array}{l}\text { Perceived } \\
\text { ease-of-use }\end{array}$} & Correlation coefficient & $0.980^{* *}$ & $* *$ & 1.000 \\
\hline & & Sig. (2-tailed) & 0.000 & & \\
\hline & & $\mathrm{N}$ & 369 & 369 & 369 \\
\hline
\end{tabular}

${ }^{* *}$ : Correlation is significant at the 0.05 level (2-tailed). Source: Field Survey Data, 2017, SPSS 21 Output.

Table 4. Correlation analysis showing the relationship between web security, perceived trust and perceived-ease-of-use.

\begin{tabular}{|c|c|c|c|c|c|}
\hline \multicolumn{6}{|c|}{ Correlations } \\
\hline & & & $\begin{array}{c}\text { Web } \\
\text { security }\end{array}$ & $\begin{array}{c}\text { Perceived } \\
\text { trust }\end{array}$ & $\begin{array}{l}\text { Perceived } \\
\text { ease of use }\end{array}$ \\
\hline & & Correlation coefficient & 1.000 & $0.989^{\star *}$ & $0.981^{\star *}$ \\
\hline & Web security & Sig. (2-tailed) & . & 0.000 & 0.000 \\
\hline & & $\mathrm{N}$ & 369 & 369 & 369 \\
\hline & & Correlation coefficient & $0.989^{* *}$ & 1.000 & $* *$ \\
\hline \multirow{5}{*}{$\begin{array}{l}\text { Spearman's } \\
\text { rho }\end{array}$} & Perceived trust & Sig. (2-tailed) & 0.000 & & \\
\hline & & $\mathrm{N}$ & 369 & 369 & 369 \\
\hline & & Correlation coefficient & $0.981^{* *}$ & $* *$ & 1.000 \\
\hline & $\begin{array}{l}\text { Perceived } \\
\text { ease of use }\end{array}$ & Sig. (2-tailed) & 0.000 & & \\
\hline & & $\mathrm{N}$ & 369 & 369 & 369 \\
\hline
\end{tabular}

**: Correlation is significant at the 0.05 level (2-tailed). Source: Field Survey Data, 2017, SPSS 21 Output.

\subsection{Technology Adoption and Relationship between Website Quality and Online Shopping}

\section{Decision:}

Table 5 reveals a spearman rank correlation coefficient of 0.512 and probability value of $0.000(\mathrm{P}<0.05)$. This result indicates that technology adoption has is a moderate positive (significant) relationship between web aesthetics and online shopping of e-tail stores in Port Harcourt. 
Table 5. Correlation analysis showing technology adoptions link website quality and online shopping.

\begin{tabular}{ccccc}
\hline \multicolumn{2}{l}{ Control variables } & Web quality & Online shopping \\
\hline & & Correlation & 1.000 & 0.512 \\
& Web quality & Significance (2-tailed) &. & 0.000 \\
$\begin{array}{c}\text { Technology } \\
\text { adoption }\end{array}$ & df & 0 & 369 \\
& $\begin{array}{c}\text { Online } \\
\text { shopping }\end{array}$ & Correlation & 0.512 & 1.000 \\
& & Significance (2-tailed) & 0.000 &. \\
& & $\mathrm{df}$ & 369 & 0 \\
\hline
\end{tabular}

**: Correlation is significant at the 0.05 level (2-tailed). Source: Field Survey Data, 2017, SPSS 21 Output.

\section{Discussion of Findings}

\subsection{Relationship between Web Aesthetics and Online Shopping}

The result of $\mathrm{Ho}_{1}$ and $\mathrm{Ho}_{2}$ indicated that very strong and positive relationship exist among web aesthetics, perceived trust and perceived ease of use with a spearman's correlation of ${ }^{\star} 0.863$ and ${ }^{\star} 0.864$. Moreover, it has been revealed that the findings of the study are in affirmation with theoretical and empirical studies of other researchers in similar subject matter. For instance, [21], observed in their study that web aesthetics has great link with trust and credibility while [48] holds that visual appearance of websites has effects on online shoppers overall impression about the site. Moreover, the responses of online shoppers shows that $63.4 \%$ of they strongly agreed that "fully colored websites are your favorite sites" and over $40.7 \%$ agreed that "word display designs of websites could attract your attention to use the sites" which also depicts a positive link between the elements of web aesthetics (symbols, colors, logo, font display etc.) and online shopping.

\subsection{Relationship between Web Interactivity and Online Shopping}

The result of $\mathrm{Ho}_{3}$ and $\mathrm{Ho}_{4}$ also indicated that very strong and positive relationship exist among web interactivity, perceived trust and perceived ease of use with a spearman's correction of ${ }^{\star} 0.988$ and ${ }^{\star} 0.980$. Moreover, it has been revealed that the findings of the study are in affirmation with theoretical and empirical studies of other researchers in similar subject matter. For instance, [28] asserted that among all the various web design attributes, interactivity stands out as a core and distinguished element that has effect on online shoppers' response towards an electronic buying environment. Even [51] opined that web-based consumers view and consider online interactivity as a criterion in evaluating the success and quality of the sites. Moreover, the responses of online shoppers show that $43.9 \%$ they strongly agreed that they enjoy websites that are designed with web-links to other relevant and similar sites. Also, $40.9 \%$ strongly agreed that "Frequently Asked Questions (FAQ) sections enhance online interactions and 
personal expressions" which also depicts a positive link between the elements of web interactivity (FAQ apps, video Chats, chat rooms etc.) and online shopping.

\subsection{Relationship between Web Security and Online Shopping}

The result of $\mathrm{Ho}_{5}$ and $\mathrm{Ho}_{6}$ also indicated that very strong and positive relationship exist among web security, perceived trust and perceived-ease-of-use with a spearman's correction of ${ }^{\star} 0.989$ and ${ }^{\star} 0.981$. Moreover, it has been revealed that the findings of the study are in affirmation with theoretical and empirical studies of other researchers in similar subject matter. For instance, [54] asserted that web security influences the choice of online shoppers during online transactions. Moreover, the responses of online shoppers show that $48.0 \%$ they strongly agreed that "they are willing to pay high price if a site is well secured and protected". Also, $48.5 \%$ strongly agreed that "they prefer sites with stronger internet security applications than others without it" which also depicts a positive link between the elements of web security (web locks, anti-virus apps, passwords etc.) and online shopping.

\subsection{Relationship between Technology Adoption, Website Quality and Online Shopping}

The result of $\mathrm{Ho}_{7}$ also indicated that significant and positive relationship exist among technology adoption, perceived trust and perceived ease of use with a spearman's correction of ${ }^{*} 0.512$. Moreover, it has been revealed that the findings of the study are in affirmation with theoretical and empirical studies of other researchers in similar subject matter. For instance Further, [57] posited that the value placed on use of technology affects the usages of internet facilities.

Moreover, the responses of online shoppers shows that $42.0 \%$ and $40.9 \%$ strongly agreed that "Age and gender can influence how one use the internet" which also depicts a positive link between the elements of technology adoption (value for technology, age, gender, educational level etc.), website quality and online shopping.

\section{Summary}

The statement of problems and significance of this study as well as the review of related literature and research methodology were presented at the initial chapters of the study. These chapters made efforts to show the need for a better comprehension of the nexus between website quality and online shopping with its impact on consumer goods e-tail stores.

For analysis, out of the 384 copies of questionnaire distributed to online shoppers residing in Rivers, AkwaIbom, Lagos and Abuja via Facebook wall post only 369 were returned and found valid for analysis using spearman's rank correlation coefficient with the aid of SPSS version 21.0. However, seven (7) hypotheses were formed and tested with results discussed at the end of Chapter four. 


\section{Conclusions}

After data analysis, we had results that lead to our findings, we therefore conclude as follows:

1) Website quality dimensions significantly relates with online shopping of e-tail stores in Nigeria.

2) Technology adoption has moderating effects on the relationships between website quality and online shopping of e-tail stores in Nigeria.

\section{Recommendations}

Based on the findings and conclusions we recommend as follows:

1) For e-tail firms to gain more customer patronage in this turbulent business environment, keen attention should be placed on web security as this has the highest positive relationship with online shopping.

2) More also, continuous investment should be made on web interactivity and web aesthetics, findings revealed that they are more effective and makes consumers to be addicted to sites with such web contents.

It should be noted that only those with a positive view of technology will maximize their organizational objectives and goals since technology adoption has been proven to possess a significant relationship on website quality and online shopping.

\section{References}

[1] Ozuru, H.N. and Akahome, J.E. (2016) Website Attributes and User Perspectives of E-Tailing Firms in Port-Harcourt, Rivers State, Nigeria. 17 th International Academy of African Business and Development Conference Proceeding, 317-342.

[2] Oppenheim, C. and Ward, L. (2006) Evaluation of Websites for B2C e-Commerce. Aslib Proceedings New Information Perceptive, 58, 237-260.

[3] Mishara, S. and Mathew, P.M. (2013) Analyzing Perceived Risks and Website in E-Retailing: A Study from India. Journal of Internet Banking and Commerce, 18, $1-14$.

[4] Dost, B.K.M., Illyas, M. and Rehman, A.C. (2015) Online Shopping Trends and Its Effects on Consumer Buying Behavior: A Case Study of Young Generation of Pakistan. Journal of Social Development, 5, 2-22.

[5] Wang, J., Gu, L. and Aiken, M. (2010) A Study of the Impact of Individual Difference on Online Shopping. International Journal of E-Business Research, 6, 52-67. https://doi.org/10.4018/jebr.2010100904

[6] Umair, C., Muhammad, R., Rizwan, F.D. and Nawal, S. (2013) The Trend of Online Shopping in 21st Century: Impact of Enjoyment in TAM Model. Asian Journal of Empirical Research, 3, 131-141.

[7] Farber, M. (2016) Consumers Are Now Doing Most of Their Shopping Online. http://www.fortune.com

[8] Salehi, M. (2012) Consumer Buying Behavior towards Online Shopping Stores in Malaysia. International Journal of Academic Research in Business and Social Science, 2, 393-395.

[9] Koo, D., Kim, J.J. and Lee, S.H. (2008) Personal Value as Underlying Motives of 
Shopping Online. Asia Pacific Journal of Marketing and Logistics, 20, 156-173.

[10] Rudolph, S. (2016) The Future of Online Retail Shopping Is Bright-Strategies and Trends. Walden University, Walden.

https://www.business2community.com/infographics/future-online-retail-shoppingbright-statistics-trends-01458175

[11] Oludayo, T. (2016) Meet Nigerias' Yahoo Boys. Business Report. https://www.iol.co.za/business-report/opinion/meet-nigerias-yahoo-boys-2052331

[12] Samson, E. (2017) Prevalence of Internet Fraud among Nigerian Youths. https://guardian.ng/saturday-magazine/prevalence-of-internet-fraud-among-nigeri an-youths/

[13] Kim, D.J., Ferrin, D.L. and Rao, H.R. (2007) A Trust-Based Consumer Decision-Making Model in Electronic Commerce: The Role of Trust, Perceived Risk, and Their Antecedents. Decision Support System, 44, 544-564.

https://doi.org/10.1016/j.dss.2007.07.001

[14] Anusha, R. (2014) A Study on Website Quality Models. International Journal of Scientific and Research Publications, 4, 2250-3153.

[15] Venkatesh, V. and Davis, F.D. (2000) A Theoretical Extension of the Technology Acceptance Model: Four Longitudinal Field Studies. Management Science, 46, 186-204. https://doi.org/10.1287/mnsc.46.2.186.11926

[16] Venkatesh, V., Morris, M.C., Davis, G.B. and Davis, F.D. (2003) User Acceptance of Information Technology: Towards a Unified View. Management Information System Quarterly, 27, 425-478. https://doi.org/10.2307/30036540

[17] Venkatesh, V. (2000) Determinants of Perceived Ease of Use: Integrating Control, Intrinsic Motivation, and Emotion into the Technology Acceptance Model. Information Systems Research, 11, 342-365. https://doi.org/10.1287/isre.11.4.342.11872

[18] Sun, H. and Zhang, P. (2006) The Role of Moderating Factors in User Technology Acceptance. International Journal of Human-Computer Studies, 64, 53-78. https://doi.org/10.1016/j.ijhcs.2005.04.013

[19] Singh, K.K. and Kumar, P. (2014) A Model for Website Quality Evaluation: A Practical Approach. International Journal of Research in Engineering and Technology, 2, 61-68.

[20] Parasuraman, A., Zaeihaml, V. and Malhorta, A. (2005) E-SQUAL: A Multiple-Item Scale for Assessing Electronic Service Quality. Journal of Retail, 6, 12-40.

[21] Lee, Y. and Chen, A. (2011) Usability Design and Psychological Ownership of a Virtual World. Journal of Management Information Systems, 28, 269-308. https://doi.org/10.2753/MIS0742-1222280308

[22] Farah, A. and Matthew, C. (2009) The Effect of Aesthetics on Web Credibility. British Computer Society, HCI, 23.

[23] Peak, D., Gibson, M. and Prybutok, V. (2011) Synergizing Positivism and Aesthetics in the Design Process of Interactive Visual Systems. Information Design Journal, 19, 103-121. https://doi.org/10.1075/idj.19.2.03gib

[24] Lee, G.G. and Lin, H.F. (2005) Customer Perceptions of e-Service Quality in Online Shopping. International Journal of Retail and Distribution Management, 33, 161-176. https://doi.org/10.1108/09590550510581485

[25] Lu, H.P. and Hsiao, K.L. (2010) The Influence of Extro/Introversion on the Intention to Pay for Social Networking Sites. Information and Management, 47, 150-157. https://doi.org/10.1016/j.im.2010.01.003

[26] Mollen, A. and Wilson, H. (2010) Engagement, Telepresence and Interactivity in 
Online Consumer Experience: Reconciling Scholastic and Managerial Perspectives. Journal of Business Research, 63, 919-925. https://doi.org/10.1016/j.jbusres.2009.05.014

[27] Wang, Y.D. and Emurian, H.H. (2005) Trust in e-Commerce: Consideration of Interface Design Factors. Journal of Electronic Commerce in Organizations, 3, 42-46. https://doi.org/10.4018/jeco.2005100103

[28] Brown, S.A. and Venkatesh, V. (2005) Model of Adoption of Technology in the Household: A Baseline Model Test and Extension Incorporating Household Life Cycle. Management Information System Quarterly, 29, 399-426. https://doi.org/10.2307/25148690

[29] Cheung, C.M.K. and Lee, M.K.O. (2006) Understanding Consumer Trust in Internet Shopping: A Multidisciplinary Approach. Journal of American Society for Information Science and Technology, 57, 479-492. https://doi.org/10.1002/asi.20312

[30] Kwek, C.L., Dazmin, B.D., Tan, H.P., Padzil, H. and Kay, H.K. (2011) Perceived Risk, Perceived Technology, Online Trust for the Online Purchase Intention in Malaysia. International Journal of Business and Management, 6, 167-168.

[31] Lim, Y.J., Abdullah, B.O. and Mohd, S.B.A. (2014) Perceived Usefulness and Trust towards Consumer Behavior: A Perspective of Consumer Online Shopping. Journal of Asian Scientific Research, 4, 541-546.

[32] Wang, C.C. and Fang, S.K.L.W. (2008) Extending the Technology Acceptance Model to Mobile Telecommunication Innovation: The Existence of Network Externalities. Journal of Consumer Behavior, 7, 101-110. https://doi.org/10.1002/cb.240

[33] Chayapa, K. and Cheng, L.W. (2011) Online Shopper Behavior: Influence of Online Shopping Decision. Asian Journal of Business Research, 1, 5-6.

[34] Lavison, R. (2013) Factors Influencing the Adoption of Organic Fertilizers in Vegetable Production in Accra. Msc Thesis, Accra Ghana.

http://hdl.handle.net/123456789/5410

[35] Benbasat, I. and Barki, H. (2007) Quo Vadis, Technology Acceptance Model? Journal of the Association for Information Systems, 8, 212-218.

[36] Bai, B., Law, R. and Wen, I. (2008) The Impact of Website Quality on Customer Satisfaction and Purchase Intentions: Evidence from Chinese Online Visitors. International Journal of Hospitality Management, 27, 391-402. https://doi.org/10.1016/j.ijhm.2007.10.008

[37] Ahn, T., Ryu, S. and Han, I. (2007) The Impact of Web Quality and Playfulness on User Acceptance of Online Retailing. Information and Management, 44, 263-275. https://doi.org/10.1016/j.im.2006.12.008

[38] Beldad, A., De Jong, M. and Steehouder, M. (2010) How Shall I Trust the Faceless and the Intangible? A Literature Review on the Antecedents of Online Trust. Computers in Human Behavior, 26, 857-869. https://doi.org/10.1016/j.chb.2010.03.013

[39] Tuch, A., Roth, S., Hornbek, K., Opwis, K. and Bargas-Avila, J. (2012) Is Beautiful Really Usable? Toward Understanding the Relation between Usability, Aesthetics. Computers in Human Behavior, 28, 1596-1607. https://doi.org/10.1016/j.chb.2012.03.024

[40] Schenkman, B. and Jonsson, F. (2000) Aesthetics and Preferences of Web Pages. Behavior and Information Technology, 19, 367-377. https://doi.org/10.1080/014492900750000063

[41] Vrechopoulos, A., O’Keefe, R.M. and Doukidis, G.I. (2000) Virtual Store Atmosphere in Internet Retailing. Proceedings of the 13 th International Bled Electronic 
Commerce Conference: Bled, Slovenia, 19-21 June 2000.

[42] Koufaris, M. and Hampton-Sosa, W. (2004) The Development of Initial Trust in an Online Company by New Customers. Information and Management System, 41, 377-397.

[43] WARC (2012) Social Media Gains Ground. http://www.warc.com/LatestNews/News/EmailNews.news?ID=29421andOrigin=W ARCNewsEmail

[44] Ahern, R.K. and Stromer-Galley, J. (2000) The Interaction Effect: An Experimental Study of High and Low Interactivity Political Websites. 50th Annual Conference of the International Communication Association, Acapulco.

[45] Jiang, Z. and Benbasat, I. (2007) Investigating the Influence of the Functional Mechanisms of Online Product Presentations. Information Systems Research, 4, 454-470. https://doi.org/10.1287/isre.1070.0124

[46] Saeed, K.A., Yujong, H. and Yi, M.Y. (2003) Toward an Integrative Framework for Online Consumer Behavior Research: A Meta-Analysis Approach. Journal of End User Computing, 15, 1-26. https://doi.org/10.4018/joeuc.2003100101

[47] Zhenhui, J., Jason, C. and Bernard, T. (2009) Effects of Interactivity on Website Involvement and Purchase Intention. Journal of the Association for Information Systems, 11, 34-59.

[48] Roggio, A. (2009) Web Design Tips. The Laws of Ecommerce Navigation Design. Practical E-Commerce.

http://www.practicalecommerce.com/articles/1131-Web-Design-Tips-The-Laws-ofEcommerce-Navigation-Design

[49] Ho, T.H.L. and Chen, Y. (2013) Vietnamese Consumers' Intention to Online Shopping Adoption: A Qualitative Approach. World, 2, 431-442.

[50] Privacy and American Business (PandAB) (2005) New Survey Reports on Increase in ID Theft and Decrease in Consumer Confidence. Conducted by Harris Interactive. http://www.pandab.org/deloitteidsurveypr.html

[51] Acquisti, A. and Grossklags, J. (2005) Privacy and Rationality in Decision Making. IEEE Security and Privacy, 3, 26-33. https://doi.org/10.1109/MSP.2005.22

[52] Shostack, A. (2003) Paying for Privacy: Consumers and Infrastructures. Proceedings of the 2nd Annual Workshop on Economics and Information Security.

[53] TNS Opinion and Social (2011) Attitudes on Data Protection and Electronic Identity in the European Union. Special Eurobarometer, 359.

[54] Janice, T., Serge, E., Lorrie, C. and Alessandro, A. (2007) The Effect of Online Privacy Information on Purchasing Behavior: An Experimental Study. WEIS.

[55] Morris, M.G., Venkatesh, V. and Ackerman, P.L. (2005) Gender and Age Difference in Employee Decisions about New Technology: An Extension to the Theory of Planned Behavior. IEEE Transactions on Engineering Management, 52, 69-84. https://doi.org/10.1109/TEM.2004.839967

[56] Techcity (2015). http://www.techcityng.com/65-of-internet-users-in-nigeria-already-shop-online-paypal/

[57] Trochim, W. (2006) The Research Methods Knowledge. Atomic Dog Publishing, Cincinnati. 